\title{
On the business cycle and new business ventures: A panel analysis of selected Southern African Development Community countries
}

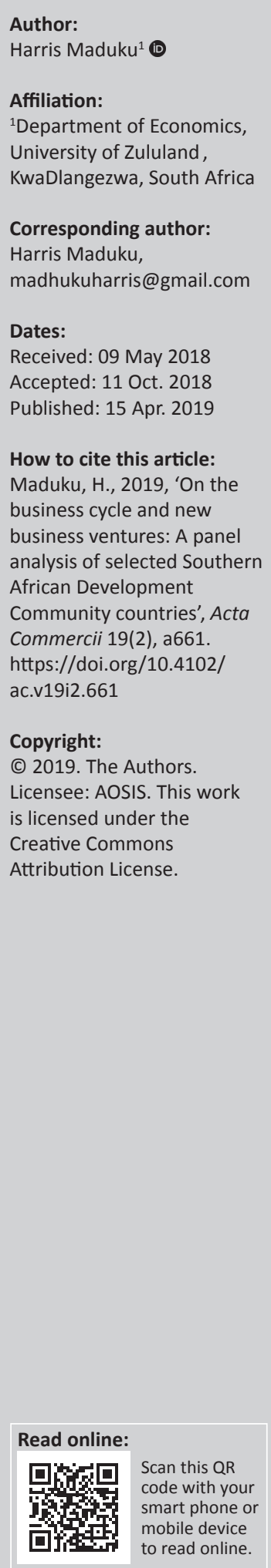

Orientation: This article investigates the relationship between entrepreneurial activities and the business cycle for selected countries in Southern African Development Community (SADC).

Research purpose: The purpose of the study was to understand how business cycle affects the supply of small businesses in the selected SADC countries.

Motivation of the study: The regional block has been witnessing low economic growth patterns accompanied by high unemployment rates, poverty and inequality leading policymakers to start looking at small business supply as a possible solution.

Research design, approach and method: The article used panel data spanning from 2000 to 2016. It also used random and fixed-effects estimation techniques.

Main findings: The study found a negative relationship between entrepreneurial activities and business cycle. Interestingly, our findings did not show either a bidirectional or unidirectional relationship between the variables of interest although they maintained an expected sign relationship as per a priori expectations. The findings also showed a negative relationship between inequality and new entrepreneurial activities and the variable is significant at the $1 \%$ level.

Practical/managerial implications: The implications of this article are that governments in these selected SADC countries prioritise nurturing small businesses so that they can grow to significantly contribute to economic growth.

Contribution/value-add: The contribution of this study is in finding the nature of the relationship that exists between the business cycle and supply of small businesses in selected SADC countries.

Keywords: entrepreneurship; new business density; business cycle; economic growth; fixed effects; random effects.

\section{Introduction}

This research focuses solely on small businesses in selected countries in Southern Africa. Small businesses are viewed as an important pillar to most developing economies, especially during this period when most developing countries are struggling with recession, unemployment and inequality (Densua \& Ng 2018). Most developing nations, especially in the Southern African Development Community (SADC) region and Africa at large, have failed to recover well after the 2008 financial world crisis. The global market and world business cycle is important to Africa because the continent has a correlation of 0.30 to the world market. South Africa alone has a correlation of 0.77 (Clark 2018). The main challenge of most economies has been recovery from recession caused by the financial crisis. In trying to spur recovery, small businesses have been pronounced as a tool that can facilitate both economic and employment growth in these economies. This provokes the need to understand how businesses react to a recession, recovery period and a boom period. Do businesses enter the market during the recovery and a boom; do they exit the market during the recession? These questions need to be answered by analysing the relationship that exists between the business cycle and new business density.

In the midst of slow growth, increasing unemployment and inequality in Africa, governments and researchers in Africa both now assert that small businesses should take the leading role on the recovery path of most economies (Densua \& Ng 2018; Schourie 2018). That has provoked huge 
increases in the volume of new entries into business, especially small businesses. Although a large number of these small businesses are operating informally in most economies, their impact on poverty, unemployment and inequality should not be overlooked. However, there has not been any attention given to the relationship between the business cycle and new business ventures in Southern Africa. Although outside the African perspective, a few papers have found a causal relationship between business ventures and the business cycle, for example Carree and Thurik (2010) and Parker (2012), little is known about the behaviour of the business venture cycle and whether their cyclical variations are related to the behaviour of the business cycle.

Carree and Thurik (2010) found a positive relationship between economic growth and entrepreneurial activities. Their work explicitly argues that more businesses are formed when the economy is performing well and fewer businesses are formed when the economy is in a recession. However, this does not reflect on the impact of unemployment and poverty nor income per capita on the formation of new businesses and economic growth. The assumption will be that if people are poor they might not have capital to start sizeable businesses that can help spur economic growth. On the other hand, Fritsch and Mueller (2004) found a positive relationship between employment growth and the business cycle, arguing that more jobs are created when the economy is on the path to a boom and fewer jobs are created during recessions. The findings posit that more businesses are formed during boom periods and fewer are formed during recessions. This means that employment is created during the phases of economic growth. Findings from Parker (2012) do not support the ability of entrepreneurship to foster economic growth in the long run and Shane (2008) concurs, arguing that small business owners lack the required ambition to continue to grow their operations so that they can become a reliable pillar of long-term growth. However, other businesses start small but become significant businesses that hire a large number of employees and contribute greatly to the national fiscus, hence refuting claims by Shane. With all these arguments, no emphasis has been placed on understanding the behaviour of business ventures in times when economic shocks are persistent and when they are temporary. In addition, it is not explicitly known if new business ventures are procyclical or countercyclical (Thurik 2014).

In an economic block like the SADC that is facing the challenge of kick-starting a significant pattern of economic growth (Berry 2002; Densua \& Ng 2018), it is of great importance for policymakers to know the kind of relationship that exists between economic shocks and new business ventures. Exploring the relationship between new business ventures and the business cycle will make explicit the role of new small business entries in economic growth patterns (Carree \& Thurik 2010). Most SADC governments have acknowledged the contribution of small businesses but for policy purposes it needs to be explicitly known how business formations behave during and after a recession so that longterm growth can be planned.
Baptista and Karaöz (2011) postulate that if it happens that there are more entries into business during an economic downturn the interest should be if these new ventures will be able to stimulate a quick economic recovery from a recession. Baptista and Karaöz argue that the entrance of new small businesses can only possess the capacity to stimulate recovery if their entries will not displace those that were already in existence. When new businesses displace already-existing businesses, the economic gains of job creation will not be enjoyed because they will be countered by job losses; hence it will be difficult for an economy to recover as a result of new entries (Baptista \& Karaöz 2011). However, this can only happen if the downturn is being caused by a failing sector or sectors in the economy while there are other sectors that start to thrive, attracting new businesses. According to another line of argument, small business ventures during a recession can only facilitate recovery if they can create supply-side spillovers to the already available incumbents (Baptista \& Karaöz 2011). This is when small businesses come in to supply inputs to big businesses that are already in operation, creating strong linkages between small and big businesses (Baptista \& Preto 2011).

Colombo, Delmastro and Grilli (2004) see the capacity of the small business owners in terms of their education status as an important aspect for the new entries to facilitate economic recovery. Their argument is rooted in the fact that, when a founder of a business has better education status, that can influence the success of the business because the person can offer better management practices to the business (Carree \& Thurik 2003). Moreover, people who are better educated have the capacity to crowdsource capital or to get credit for the business from the financial sector (Astero \& Bernhardt 2005). Their argument is based on the question of whether the new entries that come on board during an economic downturn are formed by people with better education, therefore dictating that there are high chances that the businesses created are likely to perform better as compared to those of owners with less human capital. If the businesses are owned by people with high human capital capacity then they have higher chances of success, meaning they can be counted on to facilitate or foster economic recovery (Bosma et al. 2004).

There is another kind of thinking that tries to understand the relationship between new business ventures and the business cycle. It argues that new business ventures are affected by the business cycle through profit opportunities that are available and the willingness of the entrepreneurs to take them (Parker 2009). He goes on to argue that the propensity of entrepreneurs to exploit available opportunities can help an economy to recover from a recession, and if the propensity to exploit is persistent then an economy can achieve sustainable economic growth. However, the performance of these new business ventures in an economy depends on the ratio of demand for profit opportunities available and the supply of entrepreneurs (Casson 1982). If the supply of business ventures is less than the available untapped profit opportunities (a business density undershoot), it will not foster economic recovery as 
compared to a situation where there is equilibrium between the two. During a business density overshoot where there is an oversupply of new ventures compared to the available untapped profit opportunities, again the economy will not witness an economic recovery that will facilitate sustainable growth, because businesses will be wasting resources and doing business will be costly compared to a situation of equilibrium or an undershoot (Parker 2012).

Although the idea of finding a relationship between the business cycle and entrepreneurial activity has been given some attention in Europe and Asia, the issue has not been given attention in the African context to the best knowledge of this researcher. This article aims to contribute to the body of knowledge by analysing continental and regional heterogeneity, making it the first in the SADC especially on these selected countries. The objective of this article is to critically understand and analyse the relationship between new business entries and the business cycle if that relationship exists in selected countries of the SADC. If that relationship is known, policymakers in Southern Africa, especially from the selected countries covered by this study, will then be able to come up with policies for adapting and taking advantage of that relationship. The rest of the article is divided into the literature on new business ventures and the business cycle, methodology and data issues, results presentation and discussion, and lastly the conclusion and policy recommendations.

\section{Literature review on the business cycle and new business ventures}

This section goes deeper in analysing the relationship between new business entries and the business cycle or economic shocks (positive and negative). There are few papers that have explicitly found the relationship between the business cycle and new business entries as a recurring relationship; these include Congregado, Golpe and Parker (2012) and Koellinger and Thurik (2012). Their argument rests on the fact that during a recession many people find themselves unemployed, and these people may then decide to become entrepreneurs. They may enter the market after coming up with technologically innovative ideas that can make them relevant in the market. The situation leads to a point where more jobs are created, fostering an increase in the size of consumption in the economy, and the economy can grow (output growth) (Congregado et al. 2012). In this case the new entries through their innovation are making the economy recover towards a boom. The scholars then argue that when an economy is going through a boom and unemployment is at its lowest rate, the number of new entries will drastically decline, as will the technological innovations in that economy, leading to decreasing employment opportunities, output growth and consumption; as a result, the cycle recurs.

This article will also look at Fritsch and Mueller (2004), who used German data to find a positive relationship between new business entries and unemployment. They went on to find that the relationship is countercyclical. They found new business entry rates to be very high during periods of recession compared to periods when the economy is in a boom. The scholars analysed two different periods of unemployment, a period when unemployment was very low and periods during which unemployment was high. They found that more business entries occurred in those periods where unemployment was very high. Fewer businesses are formed during low unemployment periods because more people are employed or because the opportunity cost of starting a business is higher compared to a period during which unemployment is high (Fritsch \& Mueller 2004). Statistically the effect of unemployment on new business formation is only significant when unemployment is below normal or below the trend. When unemployment is above the trend, it does not induce more new business entries. The findings agree with unemployment push theory, which states that more businesses are formed when unemployment is at its highest level (Fritsch \& Mueller 2004). The findings of this study reflect the situation in most African states that more small businesses are formed by people who find themselves unemployed, are retrenched or are trying to subsidise their low incomes. The majority of countries that have high levels of small businesses are generally characterised by high unemployment, high poverty or high inequality.

Contrary to the findings by Fritsch and Mueller (2004), Klapper, Amit and Guillen (2011) found a procyclical relationship between entrepreneurship and the business cycle (measured by GDP growth). They used new firm registrations as a measurement of entrepreneurship and employed a panel dataset of more than hundred countries for a period spanning 2002-2012. The data used in their analysis covered the period before and after the global financial crisis. In their analysis they also tried to understand how the influence of country heterogeneity when it comes to financial development affects the relationship between new business entries and business cycle. They found that countries with high rates of financial development are associated with very strong procyclical behaviour of new business entries over time. The procyclicality of new business entries is not immediate but is apparent after some time. This cyclicality of new business entries is uniform in countries with high financial development, but the case is different for those economies that are still lagging when it comes to financial development (Klapper et al. 2011).

On another kind of analysis, Scholman et al. (2011) analysed the impact of economic openness on entrepreneurial activity and business cycles. Their study used panel data for exactly 19 OECD countries using the world business cycle as a benchmark for these selected countries. Using quarterly data, the study found that in the short run or after one quarter, entrepreneurial activity increases when the business cycle of a country is lagging behind the world's business cycle, and then after 1-2 years entrepreneurial activity increases when the business cycle of a certain country is leading the global business cycle. This then means that specific countries' 
business cycles in relation to the world cycle create different entrepreneurial activity depending on the time that has been chosen for analysis.

Millán, Congregado and Román (2012) looked at the relationship between self-employment and the behaviour of the business cycle. The study used micro-data for $15 \mathrm{EU}$ countries, explicitly looking at those businesses that have not hired employees but where the owner is the only worker and focusing on what influences them to hire their first employee. The study found that own-run businesses are less likely to hire any employees during a recession, and this means that there is a procyclical relationship between the decision to hire and the business cycle. The main challenges that were observed to be causing that kind of a relationship included financing and certain experiences that the business owner had endured in the previous recession. Such challenges are the main hindrances to a business transitioning from having the owner as the sole employee to hiring other employees.

Burke and Van Stel (2014) studied the behaviour of businesses when there is disequilibrium between the supply of new businesses and the availability of untapped profitopportunities businesses want to exploit in the USA. Their findings do not concur with the basic economic orthodox, which assumes that both entry and exit of businesses contribute towards equilibrium during disequilibrium. The findings were that during a period of disequilibrium, the entry of new businesses will disequilibrate the system while the exit of firms equilibrates it. Their contrary findings go on to argue that more businesses join the system when there is an economic overshoot and fewer businesses join when there is an undershoot. The fact that new businesses join when the supply of new businesses is more than the available untapped profit opportunities and decrease when there are limited profitmaking options explicitly shows that the way entrepreneurs respond to profit option availability is not efficient; hence it is costly and very slow (Burke \& Van Stel 2014).

\section{Methodology and data issues}

This section discusses our data and presents our model. Methodologically this research models new business density to understand the role the business cycle (economic growth patterns) contributes as well as to observe the nature of the relationship that exists (bidirectional or unidirectional). In our methodology we stay close to the model of McArthur and Sachs (2005), but we add four new variables to the model: new business density, unemployment, GINI coefficient and gross savings. McArthur and Sachs (2005) explained national growth rates by growth competitive index and initial income level of countries (catch-up effect). This research assumes that entrepreneurial activities are dependent on economic development and countryspecific macroeconomic environments. This article runs two models, which are both main models.

Our main objective was to explain the long-term impact of economic growth on entrepreneurial activities, not short or medium term; hence we chose to use annual data for a period of 17 years. We were not successful in getting data for each country and each year but our panel data indicates that it is balanced. The countries chosen for this study were those African countries that appear or are involved in the Global Entrepreneurship Index. The number of countries involved here totalled 137, and there were only 9 SADC African countries on that list (Botswana, South Africa, Namibia, Swaziland, Zambia, Angola, Mozambique, Madagascar and Malawi). The number of countries came down to six after dropping Mozambique, Angola and Swaziland because of availability of data on other important variables that are included in the data set.

The article only includes six variables: (1) business cycle (GDP growth rates), which is the dependent variable in the first model representing the business cycle measures in percentage changes. The annual data were taken from the World Bank's World Development Indicators database of 2017. (2) New business density represents entrepreneurial activity in our models, and the index is computed by the Global Entrepreneurship Monitor (GEM). Annual data on new business density were taken from the GEM report for 2016 and the World Bank's World Development Indicators database for 2017. (3) GDP per capita is the average income per head for the chosen countries, and it also indicates the development state of those countries. This data are taken from the World Development Indicators database of 2017 with a base year of 2010. (4) The GINI index is an index that is computed by the World Bank indicating how unequal countries are. The variable comes in our model representing the characters of countries that are included in the sample. (5) The unemployment rate is in the model as a control variable in both models. Data on the percentage of the total labour force modelled International Labour Organisation (ILO) estimate were taken from the World Development Indicators database of 2017 as annual data. (6) Gross domestic saving, another control variable, is in the model to capture the macroeconomic environment of countries selected in the sample.

We assumed that the impact of entrepreneurial activity is dependent on economic character and the stage at which a country is. The variable new business density may reflect different types of entrepreneurs that are in a country; and the representation of this variable differs from one country to another; we did not control for this but we did control for country character and development stage. In our first model we only included a control variable that deals with economic development (GINI index) and in the second model we included a variable that controls for country character (gross domestic saving). Our models are shown as follows:

$$
\begin{array}{r}
\Delta G D P_{i t}=a+b \text { Umbployment }_{i, t-1} \\
+c N B D_{i, t-1}+d G I N I_{i, t-1}+e G D S_{i, t-1}+\varepsilon_{i t}
\end{array}
$$

For the first equation our dependent variable was business cycle, and we expected to see a negative relationship between new business density and the economic shocks that are a result of the business cycle. The second equation (model) had 
new business density as the dependent variable, and we still expected the same kind of relationship between the two main variables of our models. The hypothesis was that there exists a negative relationship between the business cycle and entrepreneurship activity. The second was that there is a bidirectional causality between the two variables, and we tested for that using the Granger causality test.

$$
\begin{aligned}
& \text { NBDit }=a+b \text { Umbployment }_{i, t-1}+C \Delta G D P_{i, t-1} \\
& + \text { dlpercapita }_{i, t-1}+e G I N I_{i, t-1}+f G D S_{i, t-1}+\varepsilon_{i t}
\end{aligned}
$$

\section{Results and discussion}

This section presents the results of testing the hypothesis that was mentioned in the methodology section. The first subsection tests the hypothesis of the impact of business cycles of the selected countries and the entrepreneurial activities in those countries; the other one tests the relationship and impact of entrepreneurial activities on business cycle measure in economic growth percentages of the selected countries. The third section covers the impact of the world business cycle on the entrepreneurial activities in the SADC countries selected in the model.

\section{Diagnostic checks}

A number of diagnostic checks were performed on the data to see if the models were appropriate for the data. The results of the diagnostic tests are presented in Appendix 1-4. The first test to be run was the correlation coefficients amongst the variables. The correlation values were important for our study in order to see the expected signs amongst variables and also to see the strength of relationships between the variables. We see that business cycle (GDP growth) and GINI index had a positive but very small coefficient (0.0487), business cycle and new business density showed a negative but very small relationship of -0.0957 , while per capita income and business cycle also showed a very weak if not almost insignificant negative relationship of -0.0006 . Unemployment and business cycle showed a positive relationship of (0.0208) with the business cycle. New business density showed a strong positive relationship with per capita income and unemployment of 0.8724 and 0.5843 , respectively. To also check if the estimated variances of residuals from the estimation were dependent on the values of the independent variables, we tested the data for heteroscedasticity using the Breusch-Pagan test. We find that the $p$-value was above 5\%, showing a $p$-value of 0.9054 , a situation that was favourable to continue with our estimation technique.

\section{Granger causality analysis of business cycle and entrepreneurial activities}

Our objective was to see if there exists a bidirectional or unidirectional relationship between business cycle and entrepreneurial activities (new business density). When analysing the pairwise causality tests of variables, care needs to be put on lag length selection because these tests are so sensitive to number of lags. To circumvent that predicament we allowed the system to choose for us using the kind of data we had and it chose two lags. The only relationship that we were concerned about was for our main variables; hence we did not analyse the other variables. The results of Granger causality are attached as Appendix 2 at the end of this article for those who have other interests, but for the purpose of this article we will leave them out.

The findings indicate that new business density (entrepreneurial activity) does not Granger cause the business cycle (GDP growth), because we find that the probability value is not significant at any level; hence we cannot reject the null hypothesis. On the other side, we also cannot reject the hypothesis that says that business cycle (GDP growth) does not Granger cause new business density (entrepreneurial activity) in the selected SADC countries.

\section{Business cycle and entrepreneurial activity}

Using the Hausman test, attached at the back of this article as Appendix 2 and 3, to determine the appropriate model for the data we decided to use the fixed effects (fe) model after rejecting the null hypothesis that the random effects model is the appropriate model for Model 1. We used random effects for Model 2. The dependent variable for the model was the business cycle of the selected SADC countries, which was the GDP growth rates of those countries in percentage terms. Amongst the independent variables in the model, unemployment was the control variable to see how the model would behave with or without its involvement. The outcome of the first model reflects that there is a negative relationship between the business cycle and entrepreneurial activity in the SADC countries. However, because the number of countries in this study is limited as a result of data availability, the findings of this study should be interpreted with caution. Nevertheless, they give a snapshot of the SADC block's behaviour when it comes to the way new business entries behave during and after a recession.

This article reflected a negative relationship between entrepreneurial activities and business cycle but the variable of interest (new business density) did not show any significance in explaining the behaviour of the business cycle. Carree et al. (2002) argued that the negative relationship between the business cycle or economic growth of an economy is linked to the fact that more people might find themselves jobless during a recession and come up with innovative ideas to start businesses so that they can make a living because paid jobs are scarce. Other variables that help to explain the behaviour of the business cycle are unemployment, inequality (GINI index) and gross domestic savings (as a percentage of GDP). All these variables were consistent with the a priori expectations and are in line with the findings of other scholars who analysed economic growth and entrepreneurship (Audretsch \&Keilbach 2004; Parker, Congregado \& Golpe 2012; Thurik 2012). Unemployment, 
inequality and gross domestic saving were significant at the $5 \%, 5 \%$ and $1 \%$ levels, respectively, and carrying the expected signs. See Table 1 .

Model 2 was run with entrepreneurial activity (new business density) as the dependent variable and again the model was controlled for employment. This time around the results of the Hausman test were inconclusive as to which model was the best one to rely on. On that note the researcher chose to lean with the assumptions that guided the random effects model and to report results found from the random effects model. The findings from the random effects model maintain a negative relationship just like Model 1 between the two main variables, and interestingly we observe that business cycle this time is found to be significant at the $10 \%$ level. This makes more sense especially from an African perspective, where most people are job seekers and mostly prefer starting a business only when they have failed to secure a job in the market.

According to the findings of this article, it is concluded that the significance of the business cycle when it comes to explaining the behaviour of entrepreneurial activity rests on the fact that more businesses in Africa are formed when the economy is not doing well or when it is undergoing a recession. Fewer small, micro and medium enterprises (SMMEs) are formed when the economy is doing well, assuming more people will be joining the labour market as employees. This is unlike some European countries where a positive relationship is found between the business cycle and new business density (see Thurik 2012). This indicates that more businesses are formed when the economy is recovering or during the boom (Acs \& Audretsch 2009; Carree \& Thurik 2010). In these economies, entrepreneurship is normally treated as a random shock if the business cycle shock is temporary and the other way if the shock is persistent.

We also found that unemployment contributes positively to entrepreneurial activities in Africa, and the variable was

TABLE 1: Estimated results over the period 2000-2016.

\begin{tabular}{lcc}
\hline Variable & Model 1 & Model 2 \\
\hline Constant & $0.007^{* * *}$ & $0.070^{*}$ \\
Unemployment & $(2.76)$ & $(-1.81)$ \\
New business density & $0.025^{* *}$ & $0.072^{*}$ \\
& $(-2.29)$ & $(1.80)$ \\
GDP growth & 0.322 & - \\
& $(-1.00)$ & - \\
Lpercapita & - & $0.078^{*}$ \\
& - & $(-1.76)$ \\
GINI index & - & $0.000^{* * *}$ \\
& - & $(4.17)$ \\
GDS & $0.023^{* *}$ & $0.001^{* * *}$ \\
& $(-2.32)$ & $(-3.22)$ \\
R-sq: within & $0.000^{* * *}$ & $0.002^{* * *}$ \\
Between & $(3.89)$ & $(3.17)$ \\
Overall & 0.2100 & 0.0547 \\
\hline
\end{tabular}

GDS, gross domestic saving; GDP, gross domestic product; Lpercapita, logged per capita income.

Level of significance, $P$-values $(*$, at $10 \% ; * *$, at $5 \%$; **, at $1 \%$ ). significant at the $10 \%$ level. In the sample of countries in the study, there are countries like South Africa and Namibia that are regarded as highly unequal countries in the world; we were expecting the inequality variable to have a negative relationship with entrepreneurial activity, and our findings confirm that. The GINI index was significant at the $1 \%$ level, which makes economic sense under the assumption that when an economy is unequal, it exposes more citizens to lower income and poverty. Hence, to earn a decent income these people will have to start entrepreneurial activity. The common scenario in highly unequal economies like South Africa is high numbers of lowly skilled labour force, high dropout rates in high school as well as the high cost of tertiary education (GEM 2012; World Bank 2006; World Bank 2015). In addition, we found gross domestic savings significant at the $1 \%$ level, explaining new business entries positively. The findings are consistent with economic theory in the sense that highly saving economies grow faster and with bigger margins compared to less saving economies. Holding onto that assumption, we would like to believe that the same happens to entrepreneurial activity the more people save. The findings indicate a strong positive relationship between saving and new business density, confirming the assumption that more businesses in Africa are funded from personal savings. People with high marginal propensity to save have higher chances of starting a new business compared to those with high propensity to consume (Baptista, Karaöz \& Mendonça 2014).

The effect of entrepreneurial activity shows a negative relationship with the global business cycle and the effect is not significant. This might be a result of the nature of the supply of entrepreneurs who are in Africa. The supply of entrepreneurs basically increase when the world or their countries are in a recession because unemployment will be high. Once the economies experience economic recovery we might witness a decrease in the supply of entrepreneurs in African economies. This might also give us the assumption that the supply of new small businesses in Africa is not persistent after a business shock, hence developing a countercyclical nature. The relationship between the global business cycle and the selected SADC countries' business cycle is positive and significant at the $1 \%$ level, as expected. African economies rely much on the world market; hence any shocks that come from the world market will choke African economies, and thus they follow the behaviour of the global business cycle. The second thing is the importance of African economies in the world market, meaning that if African economies grow significantly, the global economy responds positively to the contribution of African economies. The rest of the variables in the model are not of much importance to this argument; hence we won't report them.

\section{Conclusion and policy recommendations}

One of the objectives of GEM is to facilitate growth in empirical evidence on the relationship between entrepreneurship and economic growth. It has been very difficult to measure or to 
model entrepreneurship; hence the area has been overlooked in the mainstream economics fraternity. The current study has tried to make a critical investigation to see if the entrepreneurship variable really stands a chance of being considered a factor when economic growth strategies and policies are being crafted. The old modelling by economists has always looked at large firms that possess labour and capital that can be analysed in a production function, but it has been very difficult to model entrepreneurship or the contribution of small businesses. That justifies the scarcity of literature investigating the binary relationship between entrepreneurship and economic growth, especially from an African perspective.

The current study believes in the potential of small businesses and their contribution in offering a safety net to the poor and marginalised majority of African citizens. Most African economies are characterised by high corruption rates, poverty and high inequality, pushing more people to be exposed to harsh economic conditions. Our findings are contrary to studies for developed countries that find a positive relationship between total entrepreneurship activity and economic growth. A positive relationship was found for rich European countries categorised using GDP per capita. From a European perspective, Thurik (2012) found a negative relationship between economic growth and entrepreneurship for a number of countries they categorised as poor countries, again using per capita income. The justification of a positive relationship is supported by the size and innovativeness of these new entries as a result of an economic shock (recession or boom). Moreover, it is an indication that these countries (rich) have a large number of bigger companies that are operating in those economies enjoying economies of scale and producing highly technologically innovated products. These large companies can manage to procure highly skilled human capital to facilitate productivity; hence their contribution to economic growth becomes big and significant. However, we found a negative relationship between economic growth and entrepreurship, which is consistent with Thurik (2012), who find the same results for developing and poor European countries; this fits the countries analysed in this study well because they are all developing, mostly poor and highly unequal.

Our findings do concur with the other studies that find a negative relationship between entrepreneurial activity and business cycle (economic growth pattern). Our justifications for a negative and insignificant relationship between the two rest on the argument that there is high poverty, corruption and inequality in most African states and the amount of capital that new businesses use is not big enough to be able to influence economic growth. Hence, Africa can do well if these new entries are afforded opportunities to access finance so that they can grow big enough to significantly affect growth and directly affect unemployment and poverty. This is the reason that we see a negative relationship between entrepreneurial activity and the business cycle. This situation is different when we look at the perspective of Europe, the
USA and China, who are better funded and operating in better business environments compared to African entrepreneurs.

Further, the majority of our new entries are very small businesses that we can call 'marginal' entrepreneurs, who include individually owned businesses, backdoor entrepreneurs, artists, crafters, vendors, spaza shop owners and so on. These kinds of businesses, which are common in SADC countries, contribute little unless they are nurtured to grow so that they can also boost their capacity in terms of their ability to fund research and development, improve their human capital capacity and hence finally grow their output. This article recommends that governments budget to assist new businesses with their research and development capacities so as to improve their innovation capacities, as well as budget to improve funding opportunities for new entries so they can capacitate themselves in areas that can make them grow so that they can start to significantly contribute to economic growth.

\section{Acknowledgements}

I would like to acknowledge the huge support from Professor Irrshad Kaseeram who is my PhD supervisor; without the good professor's encouragements, my postgraduate journey would have never been this progressive. Also University of Zululand's research office for the financial support in publication.

\section{Competing interests}

The author declares that he has no financial or personal relationships that may have inappropriately influenced him in writing this article.

\section{References}

Acs, Z.J. \& Audretsch, D.B., 1990, Innovation and small firms, MIT Press, Cambridge, MA.

Astero, J. \& Bernhardt, B., 2005, 'Innovation and technological change', in J. Astero \& B. Bernhardt (eds.), Handbook of Entrepreneurship Research, pp. 364-377, Springer-Verlag, New York, USA

Audretsch, D.B. \& Keilbach, M., 2004, 'Entrepreneurship capital and economic performance', Regional Studies 38, 949-959. https://doi.org/10.1080/003434 0042000280956

Audretsch, D.B. \& Stephan, P., 1996, 'Company-scientist locational links: The case of biotechnology', American Economic Review 86, 641-652.

Audretsch, D.B. \& Thurik, A.R., 2001, 'What is new about the New Economy: Sources of growth in the managed and entrepreneurial economies', Industrial and corporate Change 10, 267-315. https://doi.org/10.1093/icc/10.1.267

Baptista, R. \& Karaöz, M., 2011, 'Turbulence in growing and declining industries', Small Business Economics 36(3), 249-270.

Baptista, R., Karaöz, M. \& Mendonça, J., 2014, 'The impact of human capital on the early success of necessity versus opportunity-based entrepreneurs', Small Business Economics 42(4), 831-847.

Baptista, R. \& Preto, M.T., 2011, 'New firm formation and employment growth: Regional and business dynamics', Small Business Economics 36, 419-442. https:// doi.org/10.1007/s11187-009-9254-y

Berry, A.E., 2002, The economics of SMMEs in South Africa, Trade and Industry Policy Strategies, Pretoria.

Bosma, N.S., Van Praag, C.M., Thurik, R. \& De Wit, G., 2004, 'The value of human and social capital investments for the business performance of startups', Small Business Economics, 23(3), 227-236.

Burke, A. \& Van Stel, A., 2014, 'The entrepreneurship enabling role of freelancers: Theory with evidence from the construction industry', International Review of Entrepreneurship 9(3), 1-28. 
Carree, M.A. \& Thurik, A.R., 2003, 'Industrial structure and economic growth', in D.B. Audretsch \& A.R. Thurik (eds.), Innovation, Industry Evolution and Employment, pp. 86-110, Cambridge University Press, Cambridge.

Carree, M.A. \& Thurik, A.R., 2010, 'The impact of entrepreneurship on economic growth', in Z.J. Acs \& D.B. Audretsch (eds.), Handbook of entrepreneurship research, pp. 437-471, Kluwer Academic Publishers, Boston, MA.

Carree, M., van Stel, A., Thurik, R. \& Wennekers, S., 2002, 'Economic development and business ownership: An analysis using data of 23 OECD Countries in the Period 1976-1996', Small Business Economics 19, 271-290.

Casson, M.C., 1982, The entrepreneur: An economic theory, University of Illinois at Urbana-Champaign's Academy for Entrepreneurial Leadership Historical Research Reference in Entrepreneurship, viewed 02 February 2018, from SSRN: https:// ssrn.com/abstract $=1496173$

Clark, P., 2018, Why you should invest in African countries - Especially after the budget speech, viewed 08 July 2018, from http://www.ashburtoninvestments. com

Colombo, M., Delmastro, M. \& Grilli, L., 2004, 'Entrepreneurs' human capital and the start-up size of new technology-based firms', International Journal of Industrial Organization 22, 1183-1211. https://doi.org/10.1016/j.ijindorg.2004. 06.006

Congregado, E., Golpe, A.A. \& Parker, S.C., 2012, 'The dynamics of entrepreneurship: Hysteresis, business cycles and government policy', Empirical Economics 43(3), 1239-1261. https://doi.org/10.1007/s00181-011-0516-6

Densua, M. \& Ng, J., 2018, Strengthening the private sector in African regiona policy-making, viewed 08 July 2018, from https://www.howwemadeitinafrica. com

Fritsch, M. \& Mueller, 2004, 'Growth regimes over time and space', Regional Studies 36, 113-124.

Global Entrepreneurship Monitor (GEM), 2012, viewed 29 September 2017, from GEM: http://www.gemconsortium.org

Hansen, H. \& Rand, J., 2014, 'The myth of female credit discrimination in African manufacturing', Journal of Development Studies 50(1), 81-96. https://doi.org/10. 1080/00220388.2013.849337

Klapper, L., Amit, R. \& Guillen, R., 2011, 'Entrepreneurship and firm formation across countries', in J. Lerner \& A. Shoar (eds.), NBER volume on international differences in entrepreneurship, pp. 170-190, University of Chicago Press, Chicago, IL.

Koellinger, P.D. \& Thurik, R., 2012, 'Entrepreneurship and the business cycle', Review of Economics and Statistics 94(4), 1143-1156. https://doi.org/10.1162/ REST_a_00224
McArthur, J.W. \& Sachs, J.D., 2005, 'The growth competitiveness index: Measuring technological advancement and the stages of development', in M.E. Porter, J.D. Sachs, P.K. Cornelius, J.W. McArthur \& K. Schwab (eds.), The Global Competitiveness Report 2001-2002, pp. 28-51, Oxford University Press, New York.

Millán, J.M., Congregado, E. \& Román, C., 2012, 'Determinants of self-employment survival in Europe', Small Business Economics 38(2), 231-258. https://doi. org/10.1007/s11187-010-9260-0

Parker, S.C., 2009, The economics of entrepreneurship, Cambridge University Press, Cambridge.

Parker, S.C., 2012, 'Entrepreneurship and the business cycle: Evidence and implications for policy makers', in P. Braunerhjelm (ed.), Swedish Economic Forum Report 2012. Entrepreneurship, Norms and the Business Cycle, Chapter 2, pp. 35-51.

Parker, S.C., Congregado, E. \& Golpe, A.A., 2012, 'Is entrepreneurship a leading or lagging indicator of the business cycle? Evidence from UK self-employment data', International Small Business Journal, 30(7), 736-753. https://doi.org/10.1177/ 0266242612437560

Philip, K., 2015, Inequality is bad for growth, viewed 09 July 2018, from https://citypress.news24.com

Satchu, A.K., 2010, 'Shining Equity Bank Shows Economy on Track', The Star Business Daily, Kenya 26 Monday, p. 1.

Scholman. A, Stel. V.S. \& Thurik.R., 2011, 'The relationship among entrepreneurial activity, business cycles and economic openness', International Enterpreneurship
and Management Journal, pp. 307-319, Springer Science + Business Media. New York, USA.

Schourie, M., 2018, BUSINESS LANDSCAPE President Ramaphosa's support of entrepreneurs and SMEs in SONA had us cheering, viewed 08 July 2018, from https://www.entrepreneurmag.co.za

Thurik, A.R., 2012, 'Entreprenomics: Entrepreneurship, economic growth and policy', in Z.J. Acs, D.B. Audretsch \& R. Strom (eds.), Entrepreneurship, growth and public policy, pp. 219-249, Cambridge University Press, Cambridge, UK.

Thurik, A.R., 2014, Entrepreneurship and the business cycle, IZA World of Labor, 90. https://doi.org/10.15185/izawol.90, Bonn, Germany.

Thurik, R., Carree, M., Van Stel, A. \& Audretsch, D.B., 2010, 'Does self-employment reduce unemployment?', Journal of Business Venturing 23(6), 673-686. https:// doi.org/10.1016/j.jbusvent.2008.01.007

Thurik, R., Van Stel, A. \& Carree, M., 2004, The effect of entrepreneurship on National Economic Growth: An analysis using the GEM Database, EIM Scales Paper N200320, EIM, Zoetermeer, NL, viewed 23 March 2018, from www.eim.net

World Bank, 2006, Kenya inside Informality: Poverty, jobs, housing and services in Nairobi's slums, report no. 36347. The World Bank, Washington DC, USA.

World Bank, 2015, World development indicators, World Bank, Washington, DC. 


\section{Appendix 1}

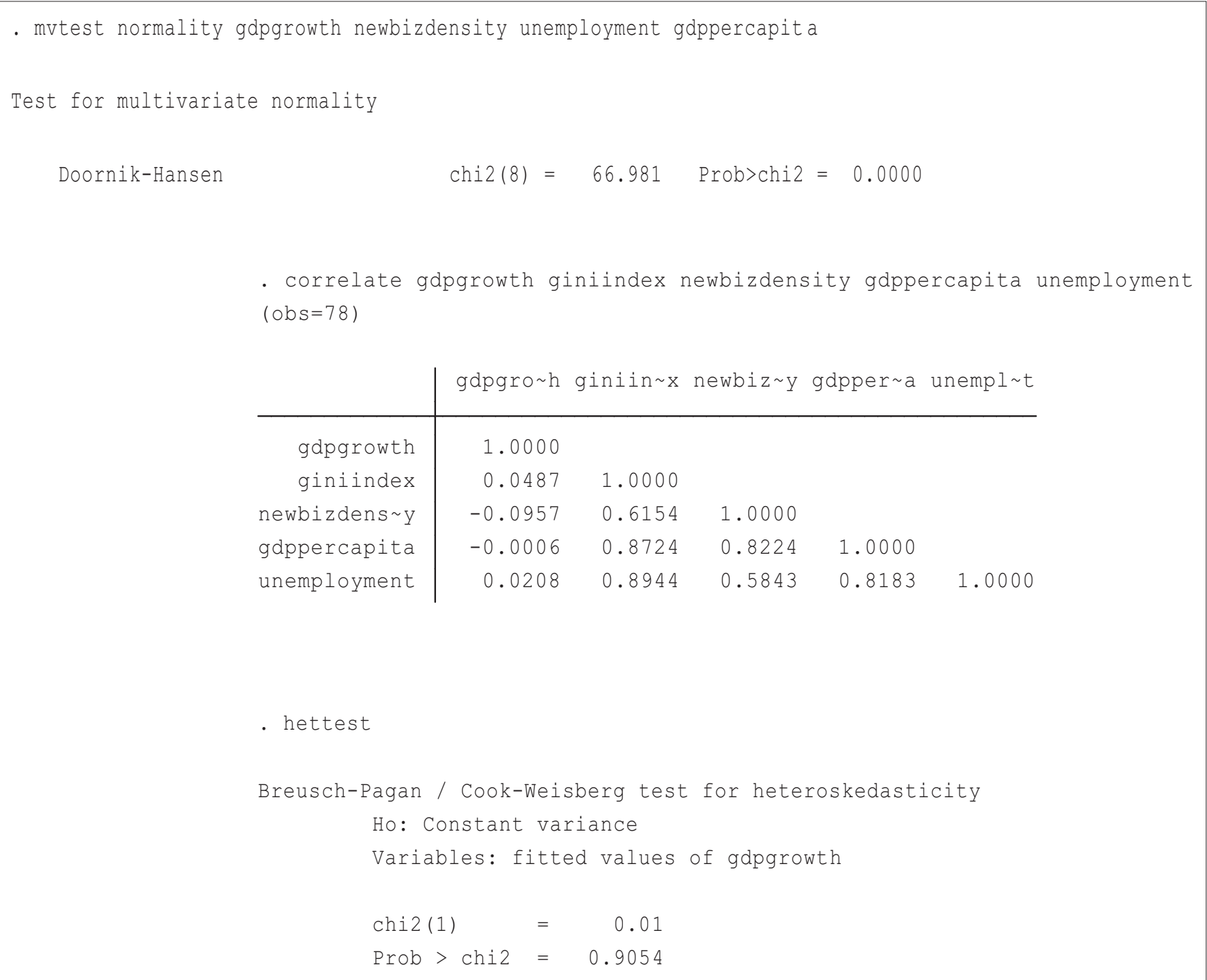

Source: Stata output (Authors' own work) 


\section{Appendix 2}

Pairwise Granger Causality Tests

Date: 03/25/18 Time: 16:55

Sample: 20002016

Lags: 2

\begin{tabular}{|c|c|c|c|}
\hline Null Hypothesis: & Obs & F-Statistic & Prob. \\
\hline NEW_BIZ_DENSITY does not Granger Cause GDP_GROWTH & 76 & 1.07427 & 0.3470 \\
\hline GDP_GROWTH does not Granger Cause NEW_BIZ_DENSITY & & 1.92982 & 0.1527 \\
\hline GINI_INDEX does not Granger Cause GDP_GROWTH & 70 & 0.20347 & 0.8164 \\
\hline GDP_GROWTH does not Granger Cause GINI_INDEX & & 4.01017 & 0.0228 \\
\hline WORLD_BIZ_CYCL does not Granger Cause GDP_GROWTH & 90 & 0.99246 & 0.3749 \\
\hline GDP_GROWTH does not Granger Cause WORLD_BIZ_CYCL & & 0.24154 & 0.7860 \\
\hline COST_OF_STARTING does not Granger Cause GDP_GROWTH & 73 & 0.57301 & 0.5665 \\
\hline GDP_GROWTH does not Granger Cause COST_OF_STARTING & & 0.89486 & 0.4134 \\
\hline GINI_INDEX does not Granger Cause NEW_BIZ_DENSITY & 61 & 0.54003 & 0.5857 \\
\hline NEW_BIZ_DENSITY does not Granger Cause GINI_INDEX & & 2.08669 & 0.1336 \\
\hline WORLD_BIZ_CYCL does not Granger Cause NEW_BIZ_DENSITY & 76 & 0.82441 & 0.4426 \\
\hline NEW_BIZ_DENSITY does not Granger Cause WORLD_BIZ_CYCL & & 0.03778 & 0.9629 \\
\hline COST_OF_STARTING does not Granger Cause NEW_BIZ_DENSITY & 73 & 0.05386 & 0.9476 \\
\hline NEW_BIZ_DENSITY does not Granger Cause COST_OF_STARTING & & 1.42947 & 0.2465 \\
\hline WORLD_BIZ_CYCL does not Granger Cause GINI_INDEX & 70 & 1.06693 & 0.3500 \\
\hline GINI_INDEX does not Granger Cause WORLD_BIZ_CYCL & & 0.06988 & 0.9326 \\
\hline COST_OF_STARTING does not Granger Cause GINI_INDEX & 58 & 0.69036 & 0.5058 \\
\hline GINI_INDEX does not Granger Cause COST_OF_STARTING & & 3.70599 & 0.0312 \\
\hline COST_OF_STARTING does not Granger Cause WORLD_BIZ_CYCL & 73 & 1.18894 & 0.3108 \\
\hline WORLD_BIZ_CYCL does not Granger Cause COST_OF_STARTING & & 0.93327 & 0.3982 \\
\hline
\end{tabular}

Source: Eviews output (Authors' own work) 


\section{Appendix 3}

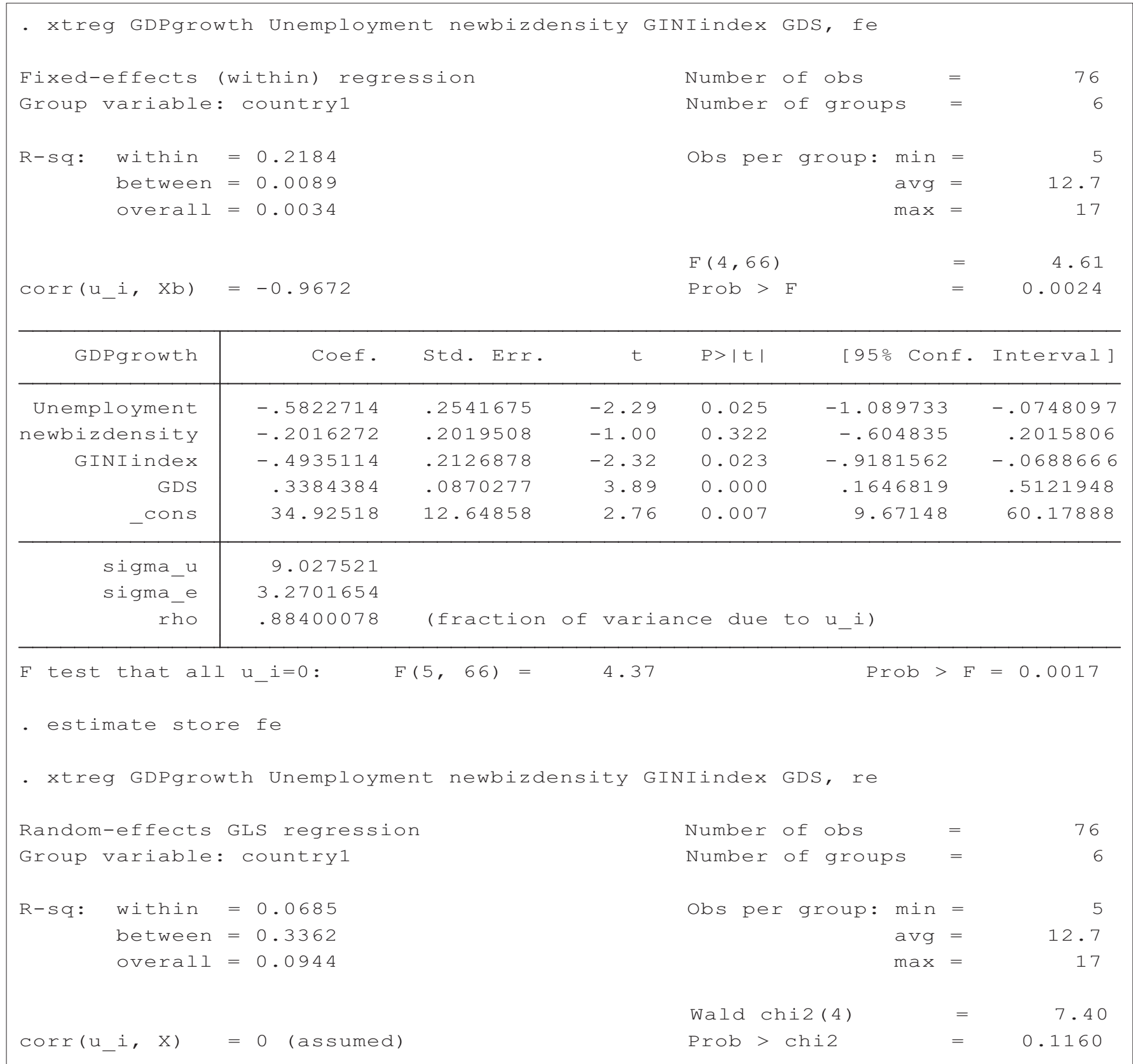




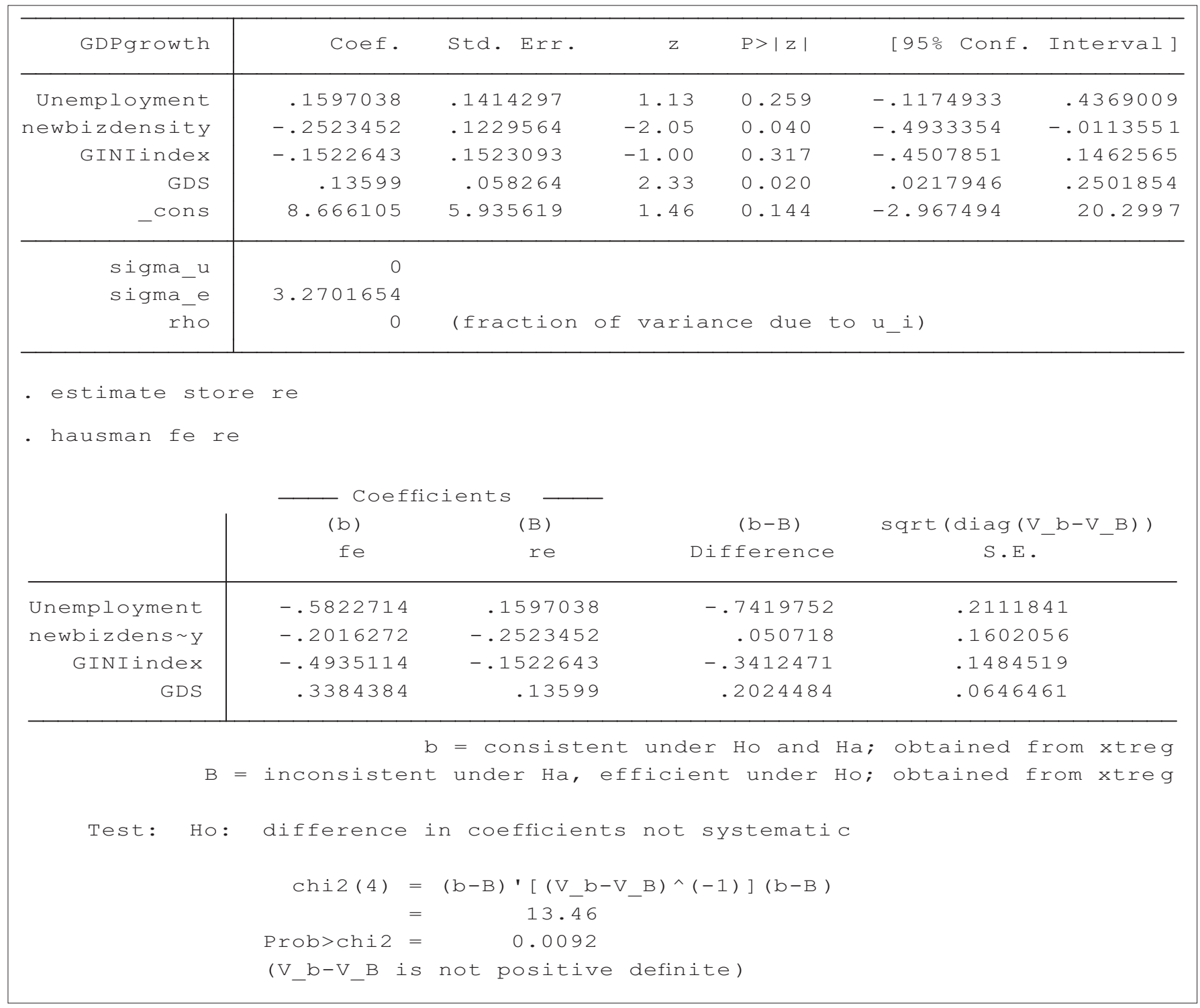

Source: Stata output (Authors' own work) 


\section{Appendix 4}

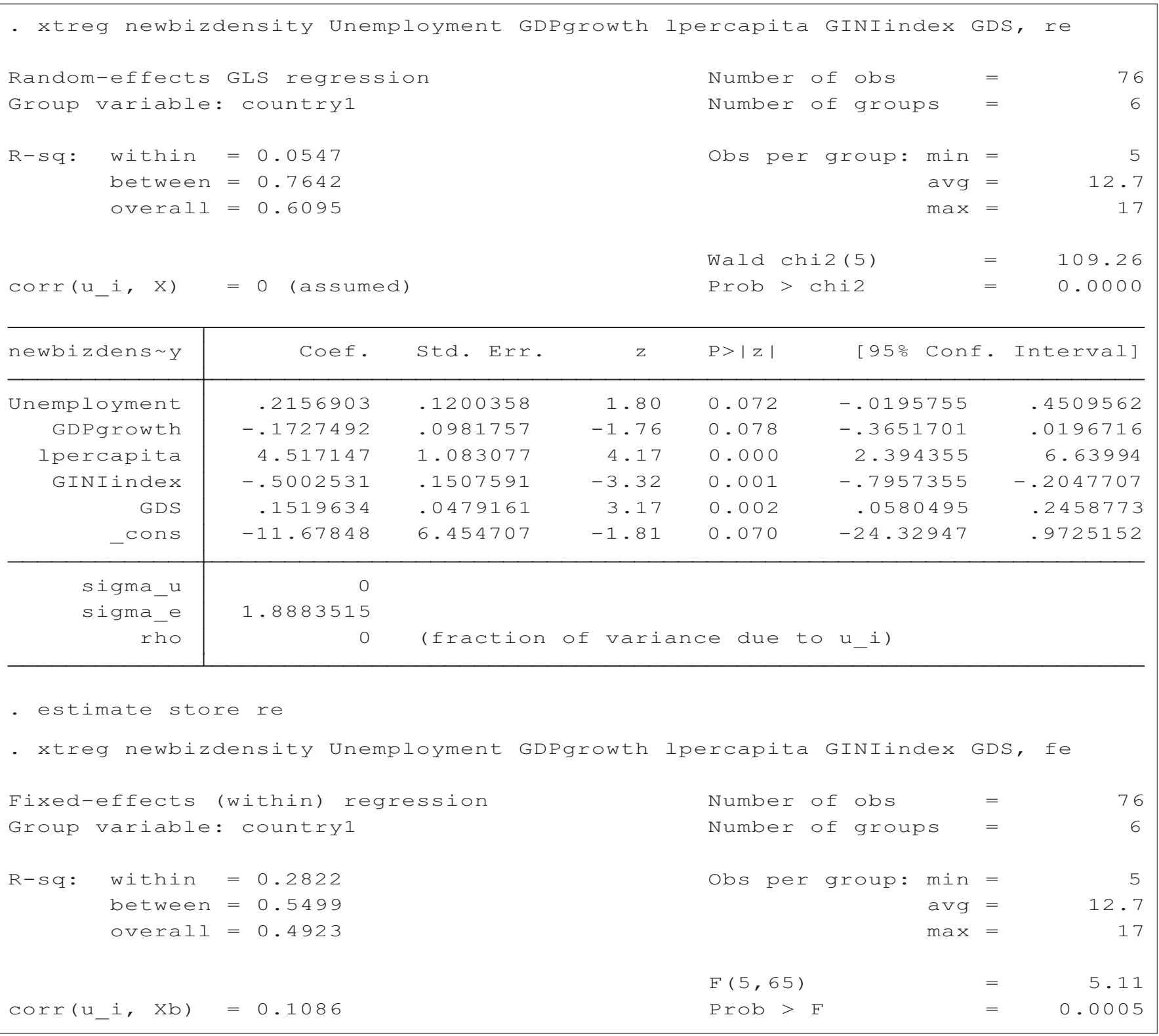

Appendix 4 continues on the next page $\rightarrow$ 


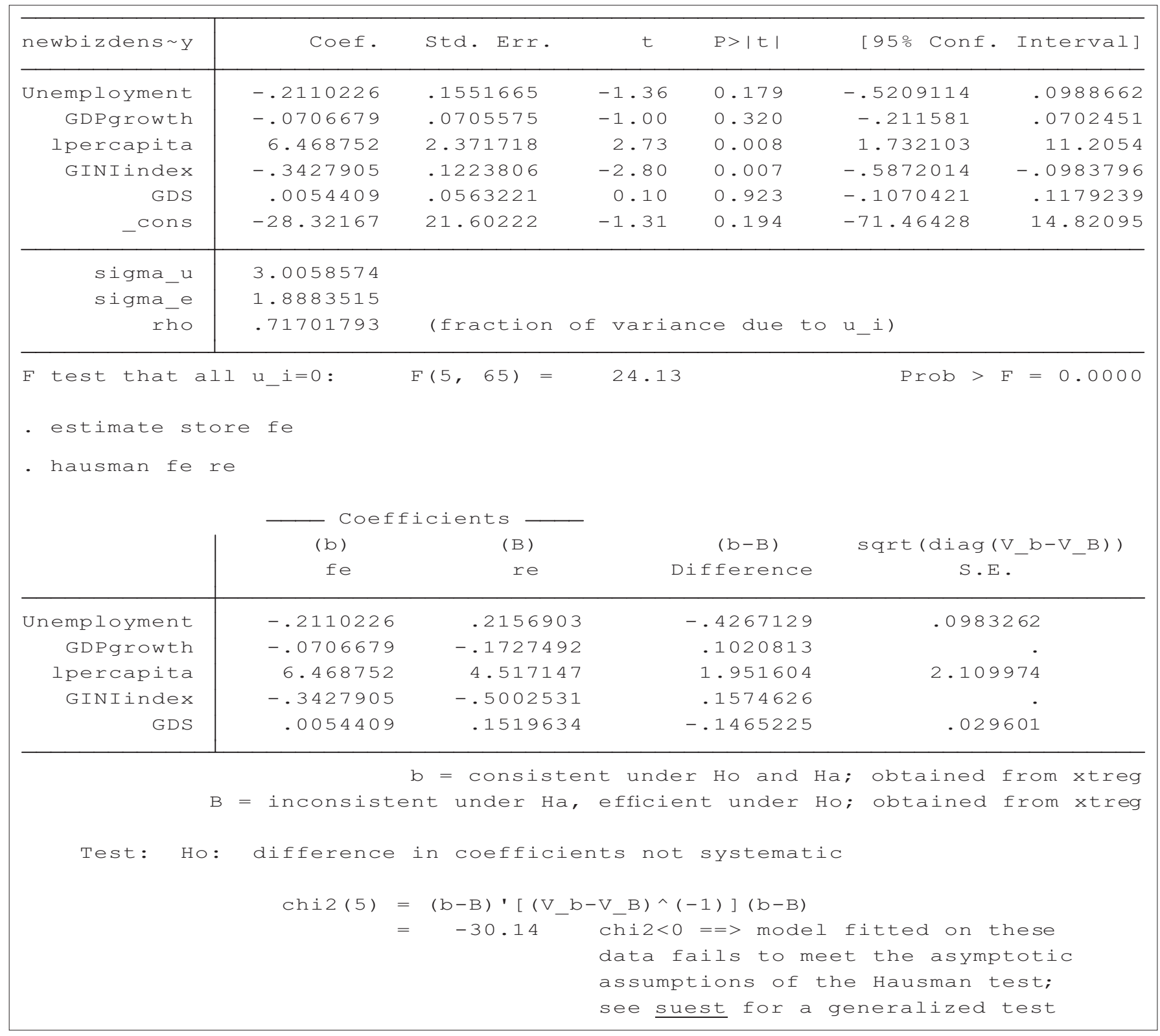

